\title{
The Effect of Organizational Culture and Perceived Organizational Support (POS) Towards Organizational Citizenship Behavior (OCB) Teacher SDK PENABUR Jakarta
}

\author{
Wahyu Kristiani ${ }^{1, a}$, Matin $^{1, b}$, Sugiarto $1, c$ \\ ${ }^{1}$ Department of Education Management, Postgraduate of State University of Jakarta, Jakarta. \\ Jl. Rawamangun Muka, Jakarta Timur 13220, Indonesia \\ Email: a wahyukristianis2@unj.ac.id; b martin@unj.ac.id; c sugiarto@unj.ac.id; \\ ${ }^{*}$ Corresponding Author
}

How to Cite : Kristiani, W., Matin, M., Sugiarto, S. (2019). The Effect of Organizational Culture and Perceived Organizational Support (POS) Towards Organizational Citizenship Behavior (OCB) Teacher SDK PENABUR Jakarta. International Journal for Educational and Vocational Studies, 1 (6), 528-532

\section{ARTICLE HISTORY}

Received: 16 June 2019

Revised: 21 July 2019

Accepted: 22 September 2019

\section{KEYWORDS}

Organizational Culture,

Perceived Organizational Support,

and Organizational Citizenship Behavior

\section{ABSTRACT}

The purpose of this research was to study the effect of organizational culture and perceived organizational support (POS) on organizational citizenship behavior (OCB) of the SDK PENABUR Jakarta teachers. The method used in this research is a survey method, using a quantitative approach. This research was conducted on SDK PENABUR teachers, with a population of 320 people, and a sample of 178 people. Sampling uses random sampling technique. Based on the research data, it can be concluded that, first there is a positive direct effect of organizational culture on OCB. Second, there is a positive direct effect of POS on OCB. Third, there is a positive direct effect of organizational culture on POS.

This is an open access article under the CC-BY-SA license.

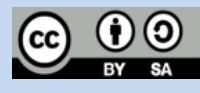

\section{INTRODUCTION}

Education has a very strategic role because it determines the quality of human resources. The strategic role of education involves educational staff, who play a role in the formation of knowledge, skills, and character. School as a formal education organization is a forum for collaboration of a group of people (educators, education staff, staff, principals, stake holders, and students) to achieve the stated goals. Achieving school goals, both in quantity and quality, is very dependent on the people gathered in the institution (school). The success of a school is determined by the teacher and the school principal as a leader in the school.

As the head of an education unit, the school principal also carries out managerial tasks that must be carried out properly. In addition, the principal has programs and targets that must be fulfilled during his tenure. The principal is expected to optimize all the potential of the school they lead through a good organizational culture to be able to create positive perceptions of the organization which will be able to optimize all existing potential resources, both internal and external in order to achieve the stated educational goals.
Successful schools need teachers who are willing to do more and having a performance that exceeds what they are expected at first. Organizations really need employees who are able to display good organizational citizenship behavior, such as helping other individuals in the team, willing to do extra work, avoiding unnecessary conflicts, respecting others, obeying the rules, and willingly tolerating work-related losses and disturbances that happened.

Every individual needs to be prepared in order to be able to play a role in facing challenges so that the organization continues to exist. In this case those teachers are required to achieve something to keep the organization to exist. Therefore the role of the organization in improving teacher performance and making teachers not in the comfort zone is very necessary. A good system must be built so that teachers will continue to change in the face of existing challenges.

BPK PENABUR also continues to develop especially in the field of education by striving to improve a good culture within the organization, namely through PKBN2K (Christian Values Based Character Education) and "PENABURS" (Professionalism, Enthusiasm, Nurture, 
Abilyty To Learn, Unselfishness, Respect to Others, Satisfaction) which animates all components of the organization's members from the teaching and educational staff as well as students. Organizational culture that occurs is expected to make improvements in the quality of teacher performance and ultimately organizational goals will be achieved.

Based on the results of a questionnaire conducted by the PENABUR Jakarta Foundation in March 2019 regarding organizational culture, namely PENABURS (Professionalism, Enthusiasm, Nurture, Ability to Learn, Believe in God, Unselfishness, Respect to Others, Satisfaction) decreased from the previous year's questionnaire results from 4.70 to 4.31 of scale 5 . This is one of the considerations for conducting research with themes related to the indicators of PENBURS.

The behavior both of teachers and student in BPK PENABUR based on the results of the survey will also affect the work behavior of educators and educators including their work culture and willingness to work beyond the demands of what they should. In this case there are two important things, namely as a factor influencing the teaching and educational staff of the foundations that shelter them, namely their work culture and their view that the foundation pays attention to the needs of the teaching and educational staff.

This study examines the direct influence of organizational culture on OCB, the direct effect of POS on OCB, and the influence of organizational culture on POS, with research subjects from SDK PENABUR Jakarta teachers.

\section{Literature Review}

McShane, Von Glinow (2011:39) defines," OCB (Organizational Citizenship Behavior) is Behaviors that extend beyond the employee's normal job duties." Schermerhorn (2010:74) defines, "Organizational Citizenship Behavior that represent a willingness to go beyond the call of duty or go to the extra mile in one's work". Organ (2004:241) defines OCB as, "OCB is individual behavior that is discretionary, not directly or explicitly recognized by the formal reward system, and that in the aggregate promotes the effective functioning of the organization".

Colquitt et al. (2015:40) wrote, "OCB going beyond normal expetations to improve operations of the organization, as well as defending the organization and being loyal to it".

Hellriegel and Slocum (2011:49) explained about organizational culture, "Organizational culture reflects the shared and learned values, beliefs, and attitudes of its members." McShane and Von Glinow (2011:416) explained: "Organizational culture consists of the values and assumptions shared within an organization. It defines what is important and unimportant in the company and, consequently, directs everyone in the organization toward the "right way" of doing things. You might think of organizational culture as the organization's DNA - invisible to the naked eye, yet a powerful template that shapes what happens in the workplace". James L. Gibson (2012:31) defines, "Organizational culture is what is what the employees perceive and how this perception creates a pattern of beliefs, values, and expectations". Edgar Schein in James L Gibson (2012:31) defines organizational cultur as: "A pattern of basic assumptions-invented, discovered, or developed by a given group as it learns to cope with the problems of external adaptation and internal integration-that has worked well enough to be considered valid and, therefore, to be taught to new members as the correct way to perceive, think, and feel in relation to those problems".

POS according to Robbins and Coulter (2012:377): "Perceived organizational support is employee's general belief that their organization values their contribution and cares about their well-being, shows that the commitment of the organization to the employee can be beneficial. High levels of perceived organizational support lead to increased job satisfaction and lower turnover". POS according to Rhoades and Eisenberger (2002:501): "Refers to employees' beliefs concerning the extent to which the organization values their contribution and cares about their well-being". POS according to (Robbins, 2013): "POS is the degree to which employees believe the organization values their contribution and cares about their well-being (for example, an employee believes his organization would accommodate him if he had a child care problem or would forgive an honest mistake on his part)".

Jayasree Krishnan and V. Shella Mary (2012:2) define "perceived organizational support is an employee belief that the organization cares for and values his or her contribution to the success of the organization". Maryam Jafari Jebeli and Akbar Etebarian (2015:2) define POS, "refers to feelings and beliefs held by individuals in terms of levels of value and respect directed by organizations towards cooperation, assistance and support to their employees."

According to Danish, Ramzan, and Ahmad (2013:313), "perceived organizational support is the expectations of employee that organization appraise their contribution and works for their welfare as well". James N. Kurtessis, Robert Eisenberger, Michael T. Ford, Louis C. Buffardi, Kathleen A. Stewart, and Cory S. Adis (2015:698) explained that POS is, "a general perception concerning the extent to which the organization values their contributions and cares about their well-being."

\section{METHODS}

The method used in this research is survey method, using a quantitative approach. This research was conducted on 320 SDK PENABUR Jakarta teachers, with a sample of 178 
people. The sampling technique used in this research is random sampling technique.

The research hypothesis that has been formulated are (1) there is a positive direct effect of organizational culture on $\mathrm{OCB},(2)$ there is a positive direct influence (POS) on OCB and (3) there is a positive direct influence of organizational culture on POS.

This research uses path analysis to determine the influence between variables tested according to the causal model formed. Before the research is conducted, a research instrument test is held to see the instrument's validity and reliability. The results will be used for research instruments and data collection. Analysis of the data used includes: 1) data description, 2) prerequisite tests for normality analysis, 3) path analysis which includes: model analysis, hypothesis testing and determination of the level of influence.

There are two variables that will be examined, they are exogenous and endogenous. Exogenous variables of organizational culture (X1) and POS (X2) are variables that are considered to influence OCB as endogenous variables (X3). The hypothetical model of research is as figure 1.

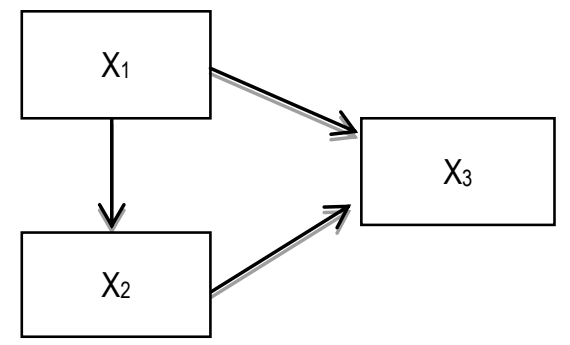

Figure 1. The hypothetical model of research

Before the research, the instrument was tested first to obtain the validity and reliability of the instrument by involving 20 SDK PENABUR Jakarta teachers. In testing the validity of instrument items for OCB variables, as many as 40 items obtained there are 7 invalid questions, namely numbers $10,11,12,14,21,22$, and 24 , so that the remaining instrument items are 33 items for OCB variables used for the next research. The calculation of instrument data reliability against 33 OCB instruments reliability coefficient of 0.966 was found. In testing the validity of the instrument items for organizational culture variables as many as 40 items obtained there are 8 invalid questions, namely numbers $18,19,24,28,30,31,34$, and 35 so that the remaining 32 items are instruments for school culture variables used in research. The calculation of reliability for 32 items of organizational culture variables reliability coefficient of 0.956 was found. In testing the validity of instrument items for empowerment variables as many as 40 items obtained there are 3 invalid questions, namely numbers 35,37 , and 38 so that the remaining 37 instrument items for POS variables used in the study. The calculation of reliability to test the consistency of the instrument against the 37 items of the variable empowerment instrument found a reliability coefficient of
0.966 .

\section{RESULTS AND DISCUSSION}

From the results of overall hypothesis testing between variables X1, X2, and X3 can be summarized through the table below:

Table 1. Summary of Proposed Hypothesis Testing Results

\begin{tabular}{cccc}
\hline \multirow{2}{*}{ Direct Influence } & \multicolumn{2}{c}{ Statistic Test } & tcount \\
\cline { 2 - 4 } & Path Coefficient & tcount & 0,01 \\
\hline X1 to X3 & 0,385 & $6,736^{* *}$ & 2,61 \\
\hline X2 to X3 & 0,478 & $8,367^{* *}$ & 2,61 \\
\hline X1 to X2 & 0,441 & $6,773^{* *}$ & 2,61 \\
\hline
\end{tabular}

Note ** very significant

Of all the path coefficient analyzes, the path analysis model is described as figure 2 .

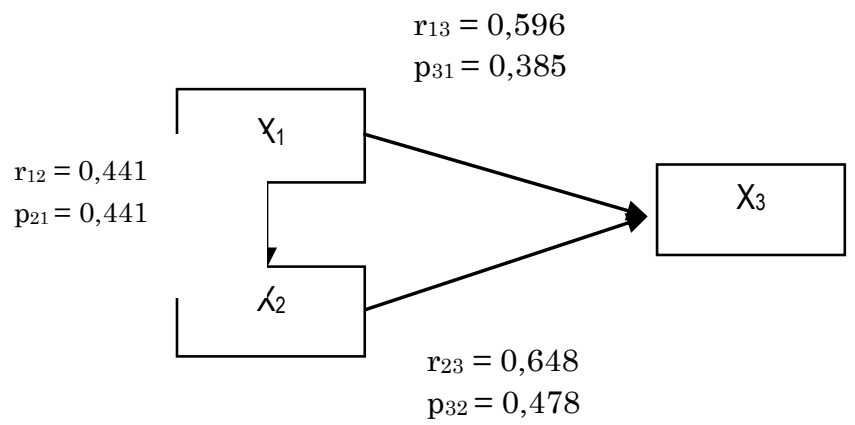

Notes:

$\mathrm{X} 1$ = Organizational Behavior, $\mathrm{X} 2=\mathrm{POS}, \mathrm{X} 3=\mathrm{OCB}$

Figure 2. path analysis model

From the first hypothesis that is, there is a direct positive influence of organizational culture on OCB, the results obtained from the calculation of the correlation coefficient $\mathrm{r} 13=0.596$ and the path coefficient value of p31 $=0.385$. This gives meaning that school culture directly influences OCB. The results of testing the first hypothesis can be concluded that there is a positive direct effect of organizational culture on OCB.

This results are matched with the result from a research in a Global Journal of Business Research titled "Influence of Organizational Culture on Organizational Citizenship Behavior: A three- Sector Study." The conclusions of the Jagannath Mohanty's research (2012:71): Organizational Culture in many ways can impact the Citizenship Behaviors of employee in an Organization. It may be concluded that there are certain factors which relate to the Culture practiced in a Workplace and which have got lot to do with inculcating the Organizational Citizenship Behavior amongst the employees. The results indicated similar results for the Organizations surveyed, which reiterates the assumption that culture if nurtured can inculcate citizenship behaviors in employees within the Organization. It can be hence speculated that strengthening the cultural roots of an Organization can lead to observance of Citizenship 
Behavior across all sectors in a given Organization.” The results of the research found evidence that Organizational Culture in many ways can have an impact on the Citizenship Behavior of employees in an Organization. It can be concluded that there are certain factors related to the culture practiced in the Workplace and which have a lot to do with the cultivation of Organizational Citizenship Behavior among employees. The results shown are the results for the organizations surveyed, which reaffirms the assumption that culture if maintained can instill citizenship behavior in employees in the Organization. Then it can be expected that strengthening the cultural roots of the Organization can lead to compliance with Citizens' Behavior in all sectors of a particular Organization.

The same research of European Journal of Business and Management, "The Effect of Organizational Culture, Organizational Commitment on the Employee Performance Trough Organizational Citizenship Behavior," by Hironimus Efendi Mandi (2019:34) states that, "Organizational cultural values and high commitment in the organization will increase the organizationalcitizenship behavior. Organizational citizenship behavior is formed from strong cultural values in the form of teamwork, building solidarity, and helping fellow coworkers who often experience difficulties in carrying out their duties. Besides a good citizenship behavior is formed from the commitment of employees and confidence in the goals of the organization, as well as obedience and loyalty to the orders given by the leadership."

At present the organizational culture implemented by SDK PENABUR Jakarta teachers is quite good, this is proven by the results of OCB shown by SDK PENABUR Jakarta teachers. A good culture will influence teachers as educators to be able to improve performance in a team. Thus, it can be concluded that when school culture strengthens, OCB will increase, based on the description it is clear that organizational culture has a direct positive effect on OCB.

In the second hypothesis, there is a positive direct effect on POS on OCB. From the results of testing the second hypothesis it can be concluded that there is a positive direct effect on POS on OCB. From the calculation results obtained the correlation coefficient $\mathrm{r} 23$ $=0.648$ and the path coefficient value of $\mathrm{p} 23=0.478$. This gives meaning that POS directly influences OCB.

The results of the research were corroborated by previous studies conducted by Sabne Pohl (2013:200) in "International Journal of Organization Theory and Behaviorl, with the title "The Impact of Organizational Support and Job Characteristics on Nurses Organizational Citizenship Behavior," that states, "As one might expect, POS have significant effect on OCB altruism and on OCB-civic virtue but only variety affects OCBs-altruism and OCB-civic virtue." As expected, POS has a significant effect on OCB-altruism and on OCB-civic virtue but only variation affects OCB-altruism and OCB-civic virtue. A research Journal that conducted by Maryam Jafari Jebeli (2015:157) in "MAGNT Research Report" entitled "Perceived Organizational Support and Organizational Citizenship Behavior," states that "According to the results from this research, there is a positive and significant relationship between perceived organizational support and organizational citizenship behavior. Accordingly, as the employee's perception of organizational support increases, the degree of organizational citizenship behavior increases as well.". The results of this study stated that there was a positive and significant effect between the support of the organizations that were felt and the behavior of organizational citizens. Thus, employees' perceptions of organizational support increase when the level of organizational citizenship behavior increases either.

A good and continually improved POS of the SDK PENABUR teachers and teacher's education will also increase OCB. Based on the description it is clear that POS has a positive direct effect on OCB.

In the third hypothesis which is formulated there is a positive direct influence regarding organizational culture on POS. It can be concluded that there is a positive direct effect of organizational culture on POS. From the calculation results obtained by the correlation coefficient $\mathrm{r} 12=0.441$ and the path coefficient value of $\mathrm{p} 21=0.441$. This gives meaning that organizational culture directly influences POS.

According to Joana Santos and Gabriela Goncalves (2014:36) in "Global Journa for research Analysis" which contains the results of their research with the title "Impact of Organizaational Culture on Employees Empowerment" explained that, "results, the Support orientation in Organizational Culture, characterized by trust and openness, is determinant for Perceived Organizational Support."

Based on the results of the expert opinion research, then trust and fidelity which are determinants of organizational culture will build positive perceptions from educators and education staff. Thus, when the organizational culture strengthens, POS are also found to be strong. Based on the description it is clear that organizational culture has a direct positive effect on POS.

\section{CONCLUSION}

Based on the results of calculations and testing of research hypotheses, it can be concluded, 1) organizational culture has a positive direct effect on OCB. Strengthening the organizational culture resulted in an increase in OCB SDK PENABUR Jakarta teachers, 2) POS directly had a positive effect on OCB. POS which increases continuously results in an increase of OCB within SDK PENABUR Jakarta teachers, 3) organizational culture has a direct positive effect on POS. This means that the improvement of organizational 
culture has resulted in the strengthening of directed and continuous empowerment efforts for the teachers of SDK PENABUR Jakarta.

\section{Suggestion}

Based on the conclusions of the research results, there are several efforts that must be done in order to improve the OCB of SDK PENABUR Jakarta teachers. It is recommended that all organizational members strengthen organizational culture and POS to increase teachers OCB in schools by conducting regular activities related to improving organizational culture in order to create a good organizational culture. There are many ways to improve OCB, namely by continually developing organizational culture starting from small things, for example by means of seminars and training related to PKBN2K and PENABURS and there is a continuous evaluation so that educators increasingly strengthen organizational culture and POS. Getting to know the value and vision and mission as an educator. Strengthen organizational culture and strengthen POS. The principal as the motor of all that is expected to also be an example and can drive a good culture and even provide rewards for educators and educators

\section{REFERENCES}

Colquitt, J. A. dkk. (2015). Organizational Behavior: Improving Performance in The Workplace. New York: McGraw-Hill.

Danish, R. Q., Ramzan, S., \& Ahmad, F. (2013). Effect of Perceived Organizational Support and Work Environment on Organizational Commitment; Mediating Role of Self-Monitoring. Advances in Economics and Business, 1(4), 312-317. https://doi.org/10.13189/AEB.2013.010402

Eisenberger, \& Huntington. (1986). Perceived Organizational Support. Journal of Applied Psychology, 71(3), 500-507.

Gibson, J. L. (2012). Organization Behavior, Structure, Process. New York: McGraw-Hill.

Mandi, Hironimus Efendi., Sunardi., Harsono., (2019). The Effect of Organizational Culture, Organizational Commitment on the Employee Performance Trough Organizational Citizenship Behavior. European Journal of Business and Management. 11(12). 34-41.

Hellriegel, D., \& Slocum, J. W. (2011). Organizational Behavior 13th Edition (13th ed.). Cengage Learning.

Jagannath Mohanty., Bhabani P Rath,. (2012). Influence of Organizational Culture on Organizational Citizenship Behavior: A Three-Sector Study, Global Journal of Business Research. 6(1), 65-76.
Jebeli, M. J., \& Etebarian, A. (2015). Perceived organizational support and organizational citizenship behavior. MAGNT Research Report, 3(4), 153-158.

Joana Santos., Gabriela., Goncalves. (2014). Organizational Culture and Perceived Organizational Support: The Impact on Professional Satisfaction, Global Journal for Research Analysis, 3(1), 33-37.

Krishnan, J., \& Mary, V. S. (2012). Perceived Organizational Support: An Overview on Its Antecedents an Consequences. Perceived Organizational Support: An Overview on Its Antecedents an Consequences, 2(4), 163-175.

Kurtessis, J. N. (2015). "Perceived Organizational Support", A Meta-Analytic Evaluation of Organizational Support Theory. Journal of Management, XX(X), 1-31.

Maryam Jafari Jebel., Akbar Etebarian., Perceived Organizational Support and Organizational Citizenship Behavior, MAGNT Research Report, 3(4), 153-158

McShane, \& Glinow, V. (2011). Organizational Behavior: emerging knowledge and practice for the real world. In McGraw -Hill international edition (Vol. 5). New York: McGraw-Hill.

Miao, R.-T. (2011). Perceived organizational support, job satisfaction, task performance and organizational citizenship behavior in China. Institue of Behavioral and Applied Management, XXXIII(2), 81-87. https://doi.org/10.1007/s13398-014-0173-7.2

Organ, D. W. (2011). Organizational Citizenship Behavior in the People'S Republic of China. Academy of Management Proceedings, 2000(1), D1-D6. https://doi.org/10.5465/apbpp.2000.5535158

Robbins, S. P., \& Coulter, M. (2012). Management. New York: Pearson.

Robbins, S. P., \& Judge, T. A. (2013). Organizational Behavior 15th Edition (15th ed.). New York: Pearson.

Sabne Pohl., Adalgisa Battistelli., Julien Librecht, (2013). the Impact of Perceived Organizational Support and Job Characteristics on Nurses' Organizational Citizenship Behaviours, International Journal of Organization Theory and Behavior, 16(2), 193-207.

Schermerhorn, J. R. (2010). Organizational Behavior 11th Edition. Ohio: ITC Garamond at Aptara 